\title{
Micro-Enterprise Owners' Loyalty Towards Their Favourite Bank: A Conceptual Framework
}

\author{
Jati Kasuma \\ Institut d'Administration des Entreprises, Universite de Toulouse 1 Capitole \\ 20, bd Lascrosses - BP 7010, 31068 Toulouse Cedex 7 \\ E-mail: jatikasuma2000@yahoo.com
}

\begin{abstract}
A loyal customer costs less to retain than acquiring a new customer. Loyal customers stick to the same service provider for a longer time period. The choice of the micro-enterprise as banks business client is influenced by a number of factors such as service quality, reputation and relationship with a brand of an organization. Apart from that, there are a number of other factors such as factors based on emotional considerations particularly cultural elements. This paper integrates previous research in the field of customer loyalty to present a conceptual framework of micro-enterprises owners' loyalty and its underlying drivers. Implication for the future research directions is also presented.
\end{abstract}

Keywords: Micro-Enterprises, SMEs, Loyalty, Ethnicity, Religiosity

\section{INTRODUCTION}

Customer loyalty is developed over a period of time by consistently meeting and exceeding the expectations of customers on a regular basis. Customer loyalty is the extent to which customers exhibit repeat purchasing behaviour from the same provider (Gremler \& Brown, 1996). Providing excellent service is the main drive to achieve customer loyalty and to sustain it for a long period of time. Today, customers are more aware that their rights and needs keep changing frequently. These factors coupled with increased competition mean that banks have to make regular improvements in their service quality to customers in order to ensure that their customers remain loyal (Kheng et al., 2010).

Micro-enterprises are more loyal to banks when they are assured that their needs are met completely. They need to feel that the whole breadth of their needs are understood and met by the bank that is serving them. As a result, wallet share and customer loyalty depend on raising the number of products used by each SME customer.

There are vast improvements in the financial markets such as internet banking, Automated Teller Machines (ATM), and phone banking. These factors together with competition from foreign players have forced bankers to delve into the significance of customer loyalty.

In today's time of global competition, it becomes very critical for banks to deliver good service and to meet the expectations of customers. Service quality plays an important role in obtaining and sustaining the loyalty of customers. The qualities that influence service quality and customer loyalty include reliability, empathy, and assurance (Kheng et al., 2010). This helps them in building a strong relationship with their customers, thus building loyalty. Customer retention is important for ensuring the bank's growth and development. Studies have shown that it is more expensive to acquire new customers than retain old customers (Beerli et al., 2004; Bloemer \& Lemmink, 1992). Customer retention helps in reducing the selling and marketing costs. This decreases the cost of operations and improves the profitability of the enterprise. Strong and loyal customer relationship have a positive impact on the long-term profitability of banks. As a result, it becomes important to understand the factors that affect customer loyalty. If the drivers for customer loyalty to banks are understood, then it helps the banks to devise customer retention initiatives accordingly (Lam et al., 2004). 


\section{LITERATURE REVIEW}

\section{Previous Research Customer Loyalty and B2B- (Small Business) Perspectives}

B2B in this study context refers to the small businesses (Perreault, 1997; Dexter \& Behan, 1999; Colgate \& Lang, 2005) or B-to-Professional (Soulez, 2007) which focuses on small entities of the business operation. The competitive business environment today has created the need for organizations and service providers to re-engineer their business strategies to achieve maximum gains and competitive advantage. Products and services offered in the B2B (small business) and B2C sectors have shorter life cycles owing to the huge influx of new products and services in the market. The multitude of choices and alternatives available to customers make it difficult for businesses to retain long-term relationships with the customers. The primary reason attributed to the reduced customer loyalty is the failure of companies to tap customers' needs and to deliver products or services in line with customers' expectations. Companies are failing to deliver their promises-giving rise to ever increasing consumer scepticism-and watching their brand loyalty suffer as a result (Watkins, 2008).

The increasing competitive market makes it difficult to retain customers over a longer period of time owing to the constant influx of new and substitute alternatives. Revenues are driven by sales, and developing customer loyalty is a key step in achieving this goal. Customer loyalty and satisfactions are some of the crucial aspects influencing the performance of products and services in the markets. Customers' loyalties are driven by customer experience that is responsible for delivering customer needs and expectations from the given product or service. Customers' experience has been explained by Watkins (2008) who mentioned that the embodiment of the brand covers all the interaction between an organization and a customer. The extent to which the brand is successful in meeting the needs and expectations of the customers' is vital in determining his satisfaction levels with the product or services offered. Strategies focusing on enhancing customer experiences help companies in generating revenue, reducing costs, retaining customers, and achieving competitive advantage (Watkins, 2008).

Retention strategies often employ measures such as consumer behaviour research and product surveys that enable the organizations to assess the needs and the expectations of the consumers which will enable them to serve customers better. Customers always appreciate the personal touch that results in building stronger relationships. Relationship management is one of the important aspects of organizational marketing strategies since it provides long term benefits and customer loyalty that is critical for retention strategies. B2B business focuses on applying customer relationship management strategies to increase market share, to build customer loyalty and to ensure efficient marketing operations (Parvatiyar \& Sheth, 2001).

One of the critical factors that drive marketing strategies is an in-depth understanding of the consumer behaviour and market trends. These are significant to the analysis of markets and help the organization to define appropriate strategies to gain competitive advantage. Positioning the brand and creating brand awareness of the intended product involve a great deal of planning and execution of advertising campaigns that will assist customers in recognizing the brand and creating brand loyalty. Effective brand loyalty strategies include the identification of target client groups, market acquisition, and understanding client needs and alternatives available in the market.

Customer behaviour in the existing business environment is driven by their quest for information related to any companies or services before making the final purchase decision. The educated consumer base today has several options to find out more about any companies, products or services through online searches and published sources. Hence, a key factor influencing customer behaviour and loyalty is corporate reputation. "Good corporate reputation benefits the company by attracting potential customers, saving the time for establishing business relationship with customers, reducing transaction cost and creating premium revenue" (Zhang, 2009). It also helps in promoting the sales of new products and developing new markets. The purchase decision of customers is influenced by the extent to which the companies diferentiate their products in terms of pricing, quality of services, and after sales services.

\section{Micro-Enterprises Owner's Loyalty: a Conceptual Framework}

Based on the above review of the literature, the researcher proposes the following model of microenterprises owners' loyalty (Figure 1) with the underlying drivers which consist of (1) Banks reputation, (2) Service quality, (3) Relationship quality and moderated factors, (1) Ethnicity and (2) Religiosity. 


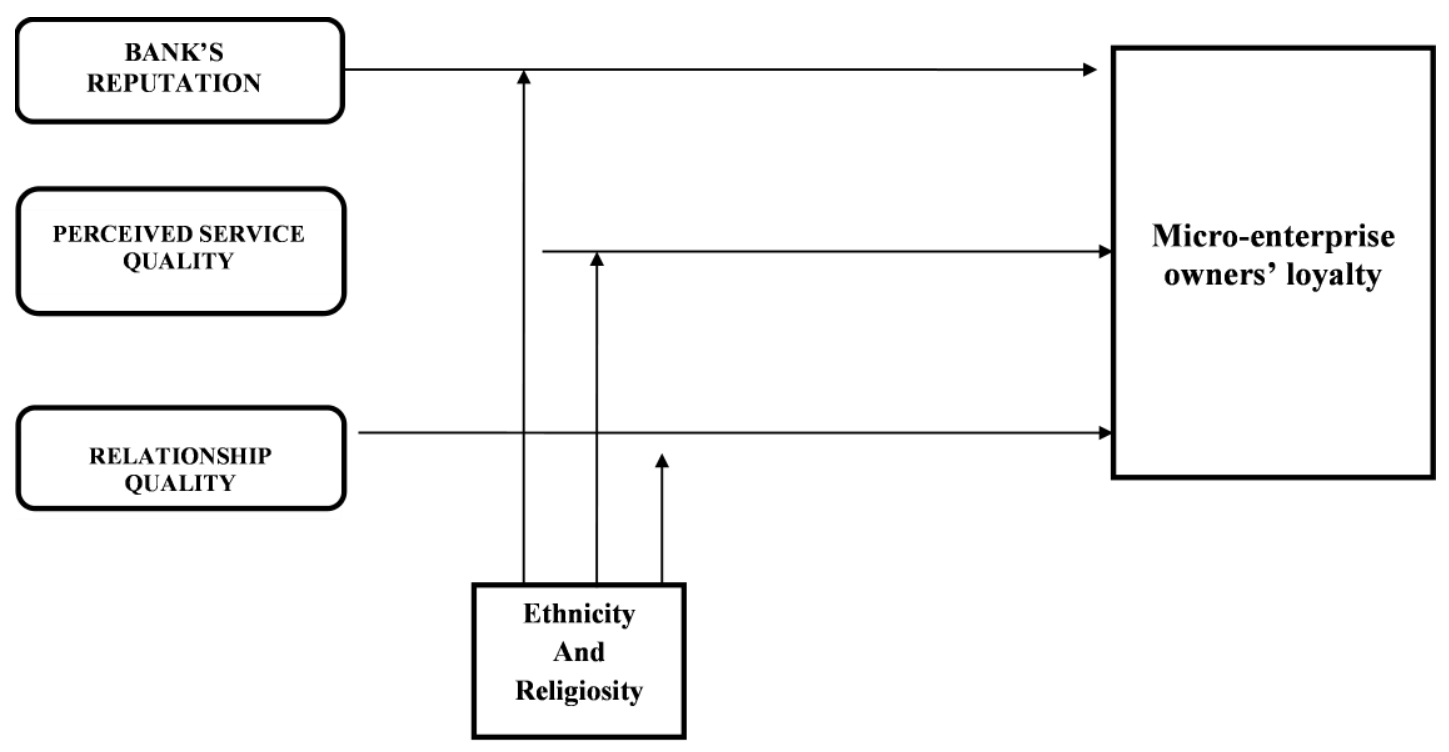

Figure 1. Micro-Enterprises Owners Loyalty Framework

\section{ANALYSIS AND DISCUSSSION}

\section{Bank's Reputation}

According to the study done by Kreps \& Decker (1993), they found that banking reputation is very important and has a very adverse effect on credit market completion, where this reputation faces many challenges in the face of competition. Furthermore, according to Aziz (2006), he highlights that for a bank to gain reputation, the bank can provide arms length lending to micro finance in which the bank makes no commitment to future refinancing if the borrower experiences financial distress. In contrast, a bank with good reputation can also provide what we call the relationship lending in where the bank promises refinancing, which could be very costly in short term. The difference between the future expected returns from arms length lending and that of relationship lending determines the banks incentives to incur any short term cost to keep its commitment and maintain a good reputation (Alreck \& Settle, 1999).

Khazeh \& Decker (1993) surveyed the opinions of 209 university students in Maryland, USA to determine customers' bank selection criteria. Service charge policy, the reputation of the bank, interest rates charged on loans, time required for loan approval and friendly tellers were identified as the top five determinants of bank selection decision. According to their study, Alreck \& Settle (1999) add that, unlike in the borrower's commitment problem to keep borrowing from the same bank in "good" times, the increased competition may strengthen a bank's incentive to keep its commitment. Banks offer loans with commitment to the highest quality borrowers but, when faced with competition from bond markets, they also give these loans to lower quality borrowers. According to Thomas \& Paolo (2006), direct borrowing in the credit markets tends to be a cheaper form of financing, but empirical research indicates that certain types of companies are eager to obtain more expensive credit by borrowing from commercial banks, even when they have the ability to issue publicly traded debt. In most cases, the reason is reputation.

Banks are typically long-lived institutions and long-term players, with an incentive to build up and maintain a reputation for being good partners to companies in financial distress. Recent research published by Erol et al. (1990) in the Review of Financial Studies reported that a commercial bank's concern for its reputation makes it likely to devote significantly more resources than public bondholders towards evaluating a borrowing company in financial distress. Thus, it is more likely to make better decisions over whether to renegotiate a loan or liquidate the business in question. The perceived advantages of borrowing from institutions such as commercial banks depend on their ability to develop and maintain a good reputation (Erol et al., 1990).

\section{Service Quality}

The quality of service offered by firms is a vital aspect of business management since it drives market growth and performance ratings. Marketing of goods and services within a global market assumes increased significance in the highly competitive 
industry environment that exposes the firms to increased pressure to deliver high quality products to its consumers (Crew \& Kleindorfer, 2009). Global markets offer the customers a host of choices, substitutes and alternatives that enable the customers to meet their needs. Therefore, the quality standards underlining the services offered assume increased significance in helping the organizations meet their marketing goals. For many years now the service encounter has been seen as central to service quality and has been termed the "moment of truth" by Carlzon (1987). Jobber \& Fahy (2009) in their book Foundations of Marketing have stated that companies that have displayed higher ratings on service quality have performed better in terms of growth in market shares and profitability.

Service quality can ensure multiple benefits from the marketing and organizational perspectives. Benefits in the marketing perspectives include improved client satisfaction, client retention, enhanced market image, and increased competitive advantage. Organizational benefits include increased efficiency in operations, leveraged cost benefit advantage, and improved awareness of quality standards resulting in greater work efficiency (Deloitte, 2010).

The quality of goods and services rendered to customers is a critical component used in the assessment of consumer satisfaction. Customer experience and satisfaction are the key element driving sales and revenues of products and services offered in the market (Grigoroudis \& Siskos, 2009). The customer experience and satisfaction in the SME financing market sector is determined by the range of products and customized services offered by financial institutions to meet the needs of the entrepreneurs.

\section{Relationship Quality}

Relationship marketing and service approach focus on developing long term relationship with customers through high priority customer service, frequent customer interaction, improved customer commitment and trust, and promoting high quality practices among workforce. Relationship quality is highlighted to assess a bank's performance from a small business perspective. Relationship quality has been conceptualized as a higher order construct made up of multiple dimensions (Crosby et al., 1990; Dorsch et al., 1998 and Dwyer et al., 1987) that is found in the psychology literature (Duck, 1992). Dwyer et al. (1987) state that relationship quality can be distinguishable by high levels of satisfaction and trust, and minimal opportunism. While Crosby et al.
(1990) and Ramsey \& Sohi (1997) use only trust and satisfaction to describe relationship quality. The whole concept of establishing long term relationship with customers is based on the "promises of low prices, promise of high quality, prompt delivery and superior service" (Kurtz et al., 2009). The consumer needs assessment and expectations will drive the market share for any product. At the end of the day, it is the consumers' satisfaction that dictates the success story of any product launch in the market. The rapid changes in the consumer behaviour drive the sales and revenues of businesses. Customer relationship strategies should focus on meeting these expectations that enhance customers' satisfaction since an understanding of the consumer needs and expectation is primarily important for planning and implementing a successful business strategy.

\section{Religiosity and Ethnicity}

Culture is inherent to the surrounding of a person or a group of persons. Hofstede (1991) in his book has defined culture as the software of the mind that guides us in our daily interactions. The impacts of religion, culture and ethnicity in driving consumer behaviour and purchase decisions have been the subject of numerous research studies and findings that they claim that religiosity and ethnicity play critical roles in influencing purchase decisions. The existing norms, beliefs, values, and symbolic meanings are important determiners in shaping individual behaviour, response patterns, pre-conceived notions, habits and preferences that in turn influence purchase decisions (Mokhlis, 2009). Religion has been identified as one of the primary forces influencing consumer behaviour. Religion and its associated practices often play a pivotal role in influencing many of the important life transitions that people experience (e.g. births, marriages, and funeral rites). They also affect values that come to be important to them (e.g. moral values of right and wrong), as well as shaping public opinion on social issues (e.g. cohabitation, pre-marital sex, family planning, organ donation, and the like), in what is allowed and forbidden for consumption (e.g. restriction on eating and drinking) and in many other aspects pertaining to everyday life (Mokhlis, 2009).

The values and beliefs promoted by religion have a distinctive impact on the consumers' perceptions and attitudes towards different products and services. Research on the impact of religion on consumer behaviour by McDaniel \& Burnett (1990) revealed that consumers who have a greater degree of religious commitment preferred to visit retail stores that have friendly sales personnel and perceived 
product quality to be significant aspects driving purchase decisions (Mokhlis, 2009). While religion and nationality do play important roles in defining consumer behaviour, researchers have also indicated that the impact of such factors is unpredictable and beyond measurement (Hofstede, 1991). Such behaviour cannot be generalized or categorized to form definitive assumptions about consumer actions or to purchase decision framing process. Consumer decision making process is often based on emotions and feelings. "In most cases, consumers do not possess a clear set of preferences to make a purchase decision when approaching different options. These are about to be constructed when individuals start processing the information on individual options" (Ahmad et al., 2009).

Financing choices of entrepreneurs in the SME sector are believed to be widely influenced by religiosity and ethnicity of the entrepreneur seeking funding (Ahmad et al., 2009). However, the extent to which such beliefs guide the choice between Islamic finance and conventional banks has not been clearly established owing to lack of vital information (Abdullah, 2010). Individual consumer decisions in normal circumstances are widely impacted by population demographic features and personal factors such as religious beliefs and nationalities. However, in the B2B consumer market segment the focus is more on price, quality, service efficiency, and partnership prospects that can provide the business with enhanced benefits (Tanner \& Raymond, 2010). Entrepreneurs are guided by profit making objectives and hence, factors such as religiosity and ethnicity take a backstage when compared to other relevant factors such as price and quality of service.

\section{CONCLUSION AND FUTURE RESEARCH}

Based on the conceptual framework of drivers of micro-enterprises owners' loyalty presented in this paper, several important future research questions arise. First, there is the need to change from the practitioners' descriptive research to a more theoretically based proposed model. For instance, there need to be:

1. Study relative importance of the need to understand the elements of ethnicity of micro-enterprises owners which might influence their loyalty towards their favourite banks in multi-culture and ethnic countries particularly in Asia.

2. Study relative importance of the need to understand the elements of faith and beliefs of microenterprises owners which might follow the spiritual belief when investing the money into specific banking concepts such as Islamic banking.
Understanding the drivers and dynamics of how micro-enterprises owners maintained their bonding with their favourite banks, with the help of an integrated theoretical framework is critical to develop future marketing strategies and approach in which will capture more attention and increase micro-enterprise owners' loyalties towards their banks.

\section{REFERENCES}

Abdullah, J. 2010. The Islamic Window: Consumer Perception and Market Research in Islamic Finance. Opalesque Islamic Finance Intelligence.

Ahmad, S. F., Uddin, M., \& Ahshanullah, M. 2009. Consumers' Reaction to Product Variety: Does Culture Matter? International Business Research, 2(3): 115-120.

Alreck, P. L. \& Settle, R. B. 1999. Strategies for Building Consumer Brand Preference. Journal of Product \& Brand Management, 8(2): 130-144.

Aziz, Z. A. 2006. Islamic Banking and Financial Progress and Prospects-Collected Speeches 2000 2006. Kuala Lumpur: Bank Negara Malaysia.

Beerli, A., Martin, J. D., \& Quintana, A. 2004. A Model of Customer Loyalty in the Retail Banking Market. European Journal of Marketing, 38(1/2): 253-275.

Bloemer, J. M. M. \& Lemmick, J. G. M. 1992. The Importance of Customer Satisfaction in Explaining Brand and Dealer Loyalty. Journal of Marketing Management, 8(4): 351-63.

Carlzon, J. 1987. Moment of Truth. New York: Harper \& Row.

Colgate, M. \& Lang, B. 2005. Positive and Negative Consequences of a Relationship Manager Strategy: New Zealand Banks and Their Small Business Customers. Journal of Business Research, 58(2): 195-204.

Crew, M. A. \& Kleindorfer, P. R. 2009. Progress in the Competitive Agenda in the Postal and Delivery Sector. Northampton: Edward Elgar Publishing Limited.

Crosby, L. A., Evans, K. R., \& Cowles, D. 1990. Relationship Quality in Services Selling: an Interpersonal Influence Perspective. Journal of Marketing, 54(3): 68-81.

Deloitte. 2010. Coping with Complexity: Leadership in Financial Services. New York: Deloitte Development.

Dexter, A. \& Behan, G. 1999. Small Business Consumers: the Emotional Economic Unit. Journal of the Market Research Society, 41(2): 171 -194 . 
Dorsch, M. J., Swanson, S. R., \& Kelley, S. W. 1998. The Role of Relationship Quality in the Stratification of Vendors as Perceived by Customers. Journal of Academy Marketing Science, 26(2): 128-142.

Duck, S. 1992. Human Relationships. London: Sage Publications.

Dwyer, F. R., Schurr, P. H., \& Oh, S. 1987. Developing Buyer-Seller Relationships. Journal of Marketing, 51(2): 11-27.

Erol, C., Kaynak, E., \& El-Bdour, R. 1990. Conventional and Islamic Banks: Patronage Behaviour of Jordanian Customers. International Journal of Bank Marketing, 8(4): 25-36.

Gremler, D. D. \& Brown, S. W. 1996. Service Loyalty: Its Nature, Importance, and Implications in Advancing Service Quality: A Global Perspective. Edvardsson: International Service Quality Association.

Grigoroudis, E. \& Siskos, Y. 2009. Customer Satisfaction Evaluation-Methods for Measuring and Implementing Service Quality. New York: Springer Publication.

Hofstede, G. 1991. Cultures and Organizations: Software of the Mind: Intercultural Cooperation and its Importance for Survival. New York: McGraw-Hill.

Jobber, D. \& Fahy, J. 2009. Foundations of Marketing. Third Edition. London: McGraw-Hill.

Khazeh, K. \& Decker, W. H. 1993. How Customers Choose Banks. Journal of Retail Banking, 14 (4): 41-44.

Kheng, L. L., Mahamad, O., Ramayah, T., \& Mosahab, R. 2010. The Impact of Service Quality on Customer Loyalty: A Study of Banks in Penang, Malaysia. International Journal of Marketing Studies, 2(2): 57-66.

Kurtz, D. L., MacKenzie, H. F. \& Snow, K. 2009. Contemporary Marketing. Scarborough: Nelson Education Limited.
Lam, S. Y., Shankar, V., Erramilli, M. K., \& Murthy, B. 2004. Customer Value, Satisfaction, Loyalty, and Switching Costs: An Illustration from a Business-To-Business Service Context. Journal of the Academy of Marketing Science, 32(3): 293-311.

McDaniel, S. W. \& Burnett, J. J. 1990. Consumer Religiosity and Retail Store Evaluative Criteria. Journal of the Academy of Marketing Science, 18 (Spring):101-112.

Mokhlis, S. 2009. Relevancy and Measurement of Religiosity in Consumer Behaviour Research. International Business Research, 2(3): 75-84.

Parvatiyar, A. \& Jagdish, N. S. 2001. Customer Relationship Management: Emerging Practice, Process, and Discipline. Journal of Economic and Social Research, 3(2): 1-34.

Perreault, J. D. 1997. Le Marketing De La PME. Economica, 2: 127-149.

Ramsey, R. P. \& Sohi, R. S. 1997. Listening to Your Customers: The Impact of Perceived Salesperson Listening Behaviour on Relationship Outcomes. Journal of the Academy of Marketing Sciences, 25(2): 127-137.

Soulez, S. 2007. Le Marketing Business-to-Professional Existetil? Actes du XXIIIème Congrès International de l'AFM, 31 Mai \& 1er Juin, Aix-les-Bains.

Tanner, J. \& Raymond, M. A. 2010. Principles of Marketing. New York: Flat World Press.

Thomas, C. \& Paolo, A. 2006. Competition and Cooperation Among Exchanges: A Theory of Cross Listing and Endogenous Listing Standards. Journal of Financial Economics, 82(2): 455-489.

Watkins, H. 2008. How to Drive Loyalty through Fantastic Customer Experiences. Kae Marketing Intelligence Report.

Zhang, Y. 2009. A Study of Corporate Reputation's Influence on Customer Loyalty Based on PLS-SEM Model. International Business Research, 2(3): 28-35. 